\title{
女子短期大学生の咬合力と体力ならびに踵骨骨密度
}

岩崎 秀哉*1 井奈波良一 $* 1$ 藤田 節也*1 吉田 英世*2

山沢 和子*3 大森 正英*4 岩田 弘敏*1

\section{Relationship between Biting Force and Physical Fitness and Calcaneus Bone Density in Students of Women's Junior College}

\author{
Hideya IWASAKI*1, Ryoichi INABA*1, Setsuya FUJITA*1, \\ Hideyo YOSHIDA*2, Kazuko YAMAZAWA*3, Masahide OMORI*4 \\ Hirotoshi IWATA*1
}

The maximum biting force (MBF) and right calcaneus bone stiffness using Ultrasonic method 91 female students aged $19.6 \pm 0.5$ years was assessed to evaluate the relations between biting force and bone density, and effect of playing sport for one of preventive measures of osteoporosis.

We took two time measurements both of left and right biting force, and adopted high measurement of those and call it maximum biting force (MBF). And we surveyed questionnaire about sport club member's period and exercise quantity.

The evaluations were made using Ultrasound Bone Densitometer and compared between the subjects who have experience of a sport club member (experienced group) and who have not experience (non-experienced group).

The results obtained were as follows.

1 The average MBF in subjects experienced group and the average stiffness of them was significantly $(\mathrm{p}<0.05)$ higher than those of the other subjects nonexperienced group.

2 There were significant positive correlations between the MBF, stiffness and grip strength $(\mathrm{p}<0.01)$, back strength $(\mathrm{p}<0.01)$ and vital capacity $(\mathrm{p}<0.05)$ in subjects experienced group. For the subjects non-experienced group no correlations

\footnotetext{
${ }^{* 1}$ 岐阜大学医学部衛生学教室

${ }^{* 2}$ 東京都老人総合研究所疫学部

*3東海女子短期大学

${ }^{* 4}$ 東海女子大学バイオサイエンス研究センター

*1 Department of Hygiene, Gifu University School of Medicine, Gifu

${ }^{*}$ Department of Epidemiology, Tokyo Metropolitan Institute of Gerontology

${ }^{* 3}$ Tokai Women's Junior College, Gifu

${ }^{* 4}$ Research Institute of Bioscience, Tokai Women's College, Gifu
} 
between MBF, stiffness and physical fitness measurements were observed.

3 To analyze multiple correlation, for subjects experienced group, there were significant $(\mathrm{p}<0.01)$ positive correlations between MBF and stiffness, but no correlations between stiffness and BMI \{Body Mass Index, height/weight $\left.\left(\mathrm{kg} / \mathrm{m}^{2}\right)\right\}$ were observed. For the subjects non-experienced group, there was a significant $(p<0.05)$ positive correlation between stiffness and BMI, but no correlations between stiffness and MBF were observed.

4 The subjects experienced group for long period or who quitted sport club in their high teens were high $\mathrm{MBF}$ and stiffness without regard to training days in a week or training hours in a day.

5 The average MBF and stiffness in subjects who are sport club members now were significantly higher than those of the other subjects non-experienced group. The average $\mathrm{MBF}$ and stiffness in subjects who quitted sport club in $17 \sim 18$ years old were significantly higher than those of the other subjects non-experienced group. But the average $\mathrm{MBF}$ and stiffness in subjects who quitted sport club in 13 14 years old were lower than those of the other subjects non-experienced group.

6 The result of questionnaire on health showed that the average MBF in subjects who answered that training for the sport in past contributes to health was significantly $(p<0.05)$ higher than those of the other subjects who answered that training for the sport in past is no correlation to health. But stiffness of the first is higher, but it's not significantly than that of second.

The above mentioned, we think that it is necessary that we should play sport which we increase biting force to increase stiffness for the purpose of preventing osteoporosis.

Key words : biting force, bone density, Physical fitness 咬合力, 骨密度, 体力

\section{I 緒言}

近年, 歯科疾患の原因となりうる叢生（叢生と は数歯が唇側舌側と交互に転位しているような場 合, 個々の歯の転位の一括した呼称）を生じさせ る歯と顎骨の大きさが不調和である者が増加して いることが報告されている(井上，1982），著者ら は, 咀嚼機能の評価法のひとつとして, 上下一対 の雪によって嚙みしめた時に出される圧力である 咬合力に着目し, さきに男性自衛官を対象に調査
を行い, 叢生の原因は顎顔面形態が縮小すること， 特に顎骨が縮小することであり, それと咬合力と の間に関係がある可能性を報告した（岩崎ら， 1995). そこで骨が縮小する要因をさぐるため, 身 体全体の骨の構成密度を示す指標である，超音波 法を用いて測定した踵骨の stiffness 值（山崎ら， 1992）と咬合力がいかなる関係にあるか知りたい と考えた。また，スポーツマンを対象にした調査 では体力測定値と咬合力との間には有意な正の相 関関係があり，スポーツ活動が咬合力を高める可 
能性を示唆した(岩崎ら, 1994)。しかし, 女性や 現在スポーツ活動を行っていない者については, 咬合力と体力との間にはどのような関係があるの かわかっていない. また, 社会問題化している骨 粗鬆症に対する予防対策のひとつとして, スポー ツクラブ活動に着目し, 過去のスポーツ活動が現 在の咬合力, 及び超音波法を用いて測定した踵骨 の stiffness とどのような関係にあるのか, すなわ ちスポーツ活動により体力測定值が向上するなら ば咬合力, 及び stiffness も向上するのかどうか知 りたいと思った。そこで今回, 著者らは, 女子短 期大学生を対象に咬合力と体力ならびに骨密度と がいかなる関係にあるのか知るために，咬合力， 骨密度測定及びスポーツ活動についてのアンケー 卜調查を行い, 咬合力と骨密度との関係を検討し た.

\section{II 対象および方法}

\section{1. 被験者}

被験者は A 女子短大の学生 (192名) のうち, 下 記の基準を満たした者91名（平均年齢19.6 00.5 歳）である。

1）電気歯髄診查の結果, 生活歯髄を有し, 冠処 置を施行していない左右上下顎第一大臼歯が健在 する。

2）上下顎第一大臼歯の近遠心的関係がアング ル I 級に分類され，かつ煩舌的に上下に嵌合して いる.

3）上下顎第二大臼歯から反対側第二大臼歯ま でに曧歯, 欠損歯, 奇形歯を認めない.

2. 方法

1）咬合力測定

恥き取り調査により習慣的咀嚼側と非習慣的咀 嚼側を確認し, 習慣的咀嚼側から咬合力を測定し た.どちらとも判別できない者は左側から測定し た. 測定法は被験者の上顎第一大臼歯の機能咬頭 である近心舌側咬頭に咬合力計（MPM3000：日 本光電工業) のセンサーの凸部位を接触させるよ うに嵌合させて，その最大咬合力を測定した。咬 合力の単位は, kgfである (森谷, 1989). 圧は単
位表面積に作用する力の大きさで表すのが普通で あるが, 咬合力ではこれを正確に求めにくいので 便宜上，上下歯で嚙んだ場合出された全圧で最大 咬合力を表している(河村, 1979)。このように最 大咬合力を 2 回ずつ測定して 2 回のうち大きい方 の値を採用した。この時, 咀嚼筋の疲労によって 咬合力が低下しないように平林（1975）の方法に 従い, 測定時間は 2 秒間とし次の測定間隔は 30 秒 以上とした。ただし最大咬合力に左右差が生じた 場合, 左右のうち大きい方の值を採用した。これ を maximum biting force (以下 MBF と略す) と して解析した。

2）骨密度測定

骨密度測定は超音波骨密度測定装置アキレス (米国ルナー社製)を使用した。この装置は被験者 の右踵骨部位を waterbath 内に置き stiffness と よばれる数值を測定するものである. stiffness と は SOS (speed of sound 超音波伝播速度) と BUA (broadband ultrasound attenuation 超音波減衰 係数）から求められる指標であり, 物理学的な骨 硬度とは異なった指標である。しかし山崎ら （1992）の報告によると, stiffness は DXA（dual energy X-ray absorptiometry 二重エネルギーX 線吸収）法の計測值と有意な正の相関関係 $(\mathrm{p}<$ 0.01）が認められること, また踵骨の SOS 及び BUA と橈骨, 腰椎, 大腿骨塩量との間には有意な 正の相関関係 $(\mathrm{p}<0.01)$ が認められること, 及び 考察で述べるように咬合力と身体の筋力との間に は有意な正の相関関係があることから stiffness は有効な指標であると考えられる。

3）体力測定

握力, 背筋力, 肺活量, 立位体前屈および伏臥 上体反らしの測定を行った。なお, 左右握力のう ち大きい方の值を maximum grip strength とし た.また, 身長, 体重を測定して, これらの值か ら BMI \{Body Mass Index: 体重/身長 ${ }^{2}(\mathrm{~kg} /$ $\left.\left.\mathrm{m}^{2}\right)\right\}$ を求めた。

4）アンケート調査

被験者にはスポーツ活動に関するアンケート調 查を行い, 過去のスポーツクラブに所属していた 
期間 (月数：以下所属期間と略記する), 過去にお いての 1 週間の練習日数，1日の練習時間， 1 週 間の練習時間（以下 1 週間の練習日数，1 日の練 習時間， 1 週間の練習時間と略記する), 入部した 年齢及び退部した年齢を調查した。現在スポーツ クラブに所属している者は過去から現在までの所 属期間とする.ここでスポーツクラブとは志望者 が自由に入退部できる学校での課外活動とする.

結果は平均值土標準偏差で示し, 有意差検定は $\mathrm{t}$ 検定または一元配置分散分析後, Scheffe の方法 で行い, $\mathrm{p}<0.05$ を有意差ありとした.

Table 1 Frequency distribution of stiffness in female students

\begin{tabular}{rrc}
\hline Stiffness & Frequency(\%) & Cumulative frequency $(\%)$ \\
\hline $65.00-$ & $1(1.1)$ & $1(1.1)$ \\
$70.00-$ & $1(1.1)$ & $2(2.2)$ \\
$75.00-$ & $10(11.0)$ & $12(13.2)$ \\
$80.00-$ & $7(7.7)$ & $19(20.9)$ \\
$85.00-$ & $18(19.8)$ & $37(40.7)$ \\
$90.00-$ & $11(12.1)$ & $48(52.7)$ \\
$95.00-$ & $13(14.3)$ & $61(67.0)$ \\
$100.00-$ & $11(12.1)$ & $72(79.1)$ \\
$105.00-$ & $6(6.6)$ & $78(85.7)$ \\
$110.00-$ & $4(4.4)$ & $82(90.1)$ \\
$115.00-$ & $5(5.5)$ & $87(95.6)$ \\
$120.00-$ & $2(2.2)$ & $89(97.8)$ \\
$125.00-$ & $1(1.1)$ & $90(98.9)$ \\
$130.00-$ & $1(1.1)$ & $91(100.0)$ \\
\hline
\end{tabular}

\section{III 結 果}

Table 1 に全員の Stiffness の度数分布を示し た。平均值は $94.7 \pm 13.3 \%$ あった. Table 2 に スポーツクラブ所属歷のある者と所属歷のない者 の MBF, stiffness 及び体力測定值を示した. 所属 歴のある者の MBF は所属歷のない者のそれより 有意に高值を示した $(\mathrm{p}<0.05)$.また，所属歴の ある者の stiffness は所属歷のない者のそれより 有意に高值を示した $(\mathrm{p}<0.05)$. 所属歷のある者 の握力は所属歴のない者のそれより有意に高值を 示した $(\mathrm{p}<0.01)$. 所属歷のある者の背筋力は所 属歷のない者のそれょり有意に高值を示した $(\mathrm{p}<0.01)$.また, 所属歴のある者の立位体前屈は 所属歴のない者のそれより有意に高値を示した $(\mathrm{p}<0.05)$. 所属歴のある者の伏臥上体反らし及 び肺活量は所属歷のない者のそれらょり高値では あったが有意な差を認めなかった. BMI は両者の 間に有意な差は認められなかった. Table 3 にス ポーツクラブの所属歴の有無別に MBF と体力測 定値との間の関係を示した. 所属歴のある者の $\mathrm{MBF}$ と握力 $(\mathrm{p}<0.01)$, 背筋力 $(\mathrm{p}<0.01)$, 肺活 量 $(\mathrm{p}<0.05)$ との間には有意な正の相関関係が認 められた.しかし MBF と立位体前屈, 伏臥上体反 らしとの間には有意な相関関係は認められなかっ た．所属歷のない者の $\mathrm{MBF}$ と体力測定值との間 には有意な相関関係は認められなかった。

Table 2 Maximum biting force(MBF), stiffness, and physical fitness measurements

\begin{tabular}{llcc}
\hline & & Sport $(+)$ & Sport $(-)$ \\
\hline $\mathrm{N}$ & & 61 & 30 \\
MBF & $(\mathrm{kgf})$ & $28.3 \pm 9.7^{*}$ & $23.6 \pm 9.1$ \\
Stiffness & & $96.5 \pm 14.5^{*}$ & $91.1 \pm 9.5$ \\
Maximum grip strength & $(\mathrm{kg})$ & $28.3 \pm 4.5^{* *}$ & $25.9 \pm 3.3$ \\
Back strength & $(\mathrm{kg})$ & $74.3 \pm 16.5^{* *}$ & $61.7 \pm 12.5$ \\
Vital capacity of lungs & $(\mathrm{ml})$ & $2,610.5 \pm 576.6$ & $2,478.7 \pm 605.3$ \\
Forward flexibility & $(\mathrm{cm})$ & $10.9 \pm 5.5^{*}$ & $7.0 \pm 7.8$ \\
Back extension & $(\mathrm{cm})$ & $50.7 \pm 7.5$ & $47.4 \pm 7.5$ \\
BMI & $\left(\mathrm{kg} / \mathrm{m}^{2}\right)$ & $21.3 \pm 2.6$ & $20.7 \pm 3.4$ \\
\hline
\end{tabular}

Each value represents the mean \pm S.D. ${ }^{*} \mathrm{p}<0.05,{ }^{* *} \mathrm{p}<0.01$ compared with Sport $(-)$. 
Table 3 Correlations between maximum biting force and physical fitness measurements

\begin{tabular}{lcc}
\hline & Sport $(+)$ & Sport $(-)$ \\
\hline Maximum grip strength & $0.578^{* *}$ & 0.022 \\
Back strength & $0.551^{* *}$ & -0.022 \\
Vital capacity of lungs & $0.424^{*}$ & 0.192 \\
Forward flexibility & 0.226 & 0.261 \\
Back extension & 0.141 & -0.077 \\
\hline & ${ }^{*} \mathrm{p}<0.05,{ }^{* *} \mathrm{p}<0.01$.
\end{tabular}

Table 4 Correlations between stiffness and physical fitness measurements

\begin{tabular}{lcc}
\hline & Sport $(+)$ & Sport $(-)$ \\
\hline Maximum grip strength & $0.464^{* *}$ & 0.335 \\
Back strength & $0.308^{*}$ & 0.088 \\
Vital capacity of lungs & $0.316^{*}$ & -0.031 \\
Forward flexibility & -0.064 & 0.416 \\
Back extension & -0.008 & 0.757 \\
\hline & ${ }^{*} \mathrm{p}<0.05,{ }^{* *} \mathrm{p}<0.01$.
\end{tabular}

Table 5 Correlations between stiffness and each of maximum biting force (MBF) and BMI

\begin{tabular}{lllc}
\hline & \multicolumn{2}{c}{ Partial correlation coefficient } & $\begin{array}{c}\text { Multiple } \\
\text { correlation } \\
\text { coefficient }\end{array}$ \\
\cline { 2 - 4 } MBF & BMI & $0.546^{* *}$ \\
Sport $(+)$ & $0.504^{* *}$ & 0.213 & 0.449 \\
\hline Sport $(-)$ & 0.125 & $0.423^{*}$ & $0.05,{ }^{* *} \mathrm{p}<0.01$.
\end{tabular}

Table 4 にスポーツクラブの所属歴の有無別に stiffness と体力測定值との間の関係を示した. 所 属歴のある者の stiffness と握力 $(\mathrm{p}<0.01)$, 背筋 力 $(\mathrm{p}<0.01)$, 肺活量 $(\mathrm{p}<0.05)$ との間には有意 な正の相関関係が認められた。しかし stiffness と 立位体前屈, 伏臥上体反らしとの間には有意な相 関関係は認められなかった。所属歴のない者の stiffness と体力測定値との間には有意な相関関係 は認められなかった。

次に stiffness を目的变数に, MBF, BMI $\{$ 体重 $(\mathrm{kg}) /$ 身長 $\left.^{2}(\mathrm{~m})\right\}$ を説明変数にして重回帰分析を 行い, その結果を Table 5 に示した. 所属歷のあ る者の stiffness と MBF との間には有意な正の 相関関係を認めた $(\mathrm{p}<0.01)$ が， stiffness と BMI 及び所属歴のない者の stiffness と MBF との間 には有意な相関関係は認められなかった。しかし 所属歴のない者の stiffness と BMI との間には有 意な正の相関関係を認めた $(\mathrm{p}<0.05)$.

Table 6 に MBF, stiffness と練習状態との相 関関係を示した。所属期間と $\mathrm{MBF}(\mathrm{p}<0.05), 1$ 日の練習時間 $(\mathrm{p}<0.01), 1$ 週間の練習時間 $(\mathrm{p}<$ $0.01)$ ，退部した年齢（ $\mathrm{p}<0.01 ） と の$ 間には有意 な正の相関関係を認めた。また入部した年齢との 間には有意な負の相関関係を認めた $(\mathrm{p}<0.05)$. このことは, 所属期間が長い者は $\mathrm{MBF}$ が大きく 1 日及び 1 週間の練習時間が長い者であり, 入部 した年齢が早く，退部した年齢が遅い傾向にある ことを表している。退部した年齢と入部した年齢

Table 6 Correlations between training conditions and each of maximum biting force (MBF) and stiffness

\begin{tabular}{lccccc}
\hline & $\begin{array}{c}\text { Period } \\
\text { (months) }\end{array}$ & $\begin{array}{c}\text { Days } \\
\text { in a week }\end{array}$ & $\begin{array}{c}\text { Hours } \\
\text { in a day }\end{array}$ & $\begin{array}{c}\text { Hours } \\
\text { in a week }\end{array}$ & $\begin{array}{c}\text { Age of quitting } \\
\text { sport club }\end{array}$ \\
\hline MBF & $0.254^{*}$ & -0.201 & -0.075 & -0.140 & 0.209 \\
Stiffness & 0.220 & -0.004 & -0.005 & -0.003 & 0.227 \\
Period (months) & - & 0.201 & $0.365^{* *}$ & $0.357^{* *}$ & $0.776^{* *}$ \\
Days in a week & 0.201 & - & $0.474^{* *}$ & $0.771^{* *}$ & $0.270^{*}$ \\
Hours in a day & $0.365^{* *}$ & $0.474^{* *}$ & - & $0.903^{* *}$ & $0.268^{*}$ \\
Hours in a week & $0.357^{* *}$ & $0.771^{* *}$ & $0.903^{* *}$ & - & $0.297^{*}$ \\
Age of joining sport club & $-0.285^{*}$ & 0.074 & -0.176 & -0.133 & $0.319^{*}$ \\
\hline
\end{tabular}


Table 7 Maximum biting force (MBF), stiffness and training conditions classified age of quitting sport club

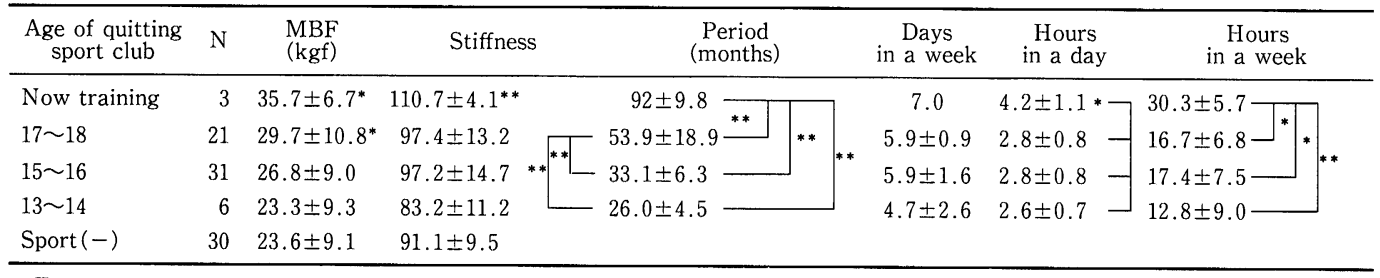

Each value represents the mean \pm S.D.

${ }^{*} \mathrm{p}<0.05,{ }^{* *} \mathrm{p}<0.01 \quad$ compared with sport $(-)$.

Table 8 Correlations between training conditions and each of maximum biting force (MBF) and stiffness in subjects classified answer how sport influence to health

\begin{tabular}{llrrr}
\hline & & N & MBF & Stiffness \\
\hline \multirow{4}{*}{ Period (months) } & (1) Wrong to health & 8 & 0.580 & $0.908^{* *}$ \\
& (2) No connection to health & 32 & -0.218 & -0.230 \\
& (3) Contribution to health & 21 & $0.626^{* *}$ & 0.380 \\
\hline \multirow{3}{*}{$\begin{array}{l}\text { Age of quitting } \\
\text { sport club }\end{array}$} & (1) Wrong to health & 8 & 0.281 & 0.666 \\
& (2) No connection to health & 32 & -0.240 & -0.130 \\
& (3) Contribution to health & 21 & $0.686^{* *}$ & $0.440^{*}$ \\
\hline & & & ${ }^{*} \mathrm{p}<0.05,{ }^{* *} \mathrm{p}<0.01$.
\end{tabular}

$(\mathrm{p}<0.05) ， 1$ 週間の練習日数 $(\mathrm{p}<0.05) ， 1$ 日の 練習時間 $(\mathrm{p}<0.05), \quad 1$ 週間の練習時間 $(\mathrm{p}<0.05)$ との間には有意な正の相関関係が認められた。こ のことは，退部した年齢が遅い者は，入部した年 齢が遅く，1 週間の練習日数が多く，1日及び 1 週間の練習時間が長い傾向にあることを表してい る. 1 週間の練習日数と 1 日の練習時間 $(\mathrm{p}<$ 0.01)， 1 週間の練習時間 $(\mathrm{p}<0.01)$ との間には 有意な正の相関関係が認められた。このことは, 1 週間の練習日数が多い者は，1 日及び 1 週間の 練習時間が長い傾向にあることを表している。し かし MBF 及び stiffness と 1 週間の練習日数， 1 日及び 1 週間の練習時間との間には有意な相関関 係は認められなかった。このことが, MBFや stiffness は 1 週間の練習日数や練習時間とは関係 がなく，所属期間が長い者や退部した年齢が遅い 者が大きい傾向にあることを表している.

Table 7 に退部した年齢で被験者を分類し，そ の MBF と stiffness を示した. 現在所属している 者の MBF $(\mathrm{p}<0.05)$ ， stiffness（p<0.01）はい
ずれも所属していない者より有意に高值を示し た. 次に $17 \sim 18$ 歳時に退部した者の MBF は所属 していない者より有意に高值を示した $(\mathrm{p}<$ 0.05).stiffness は有意ではないが, 高值を示した。 次に15〜16歳時に退部した者の MBF, stiffness は所属していない者より有意ではないが，高值を 示した. 13〜14歳時に退部した者の MBF と stiffness は所属しなかった者のそれより有意では ないが低值であった。

次にアンケートの質問項目の,「過去にスポーツ クラブに所属していたことが現在の健康状態にど のような影響を及ぼしていると思いますか」につ いて，(1)「健康状態を悪くした」，(2)「現在の健康 状態とは無関係だ」, (3)「現在の健康増進に貢献し ている」とアンケートの答えにより被験者を分類 して, その所属期間(月), 退部した年齢と MBF, stiffness との間の相関関係を Table 8 に示した。 (3)「現在の健康増進に貢献している」と答えた者 の所属期間と $\mathrm{MBF}$ との間 $(\mathrm{p}<0.01)$ また退部し た年齢と MBF $(\mathrm{p}<0.01)$ ， stiffness $(\mathrm{p}<0.05)$ 
Table 9 Maximum biting force (MBF), stiffness and training conditions classified answer how sport influence to health

\begin{tabular}{|c|c|c|c|c|c|c|c|}
\hline & $\mathrm{N}$ & $\begin{array}{l}\text { MBF } \\
(\mathrm{kgf})\end{array}$ & Stiffness & $\begin{array}{c}\text { Period } \\
\text { (months) }\end{array}$ & $\begin{array}{l}\text { Age of } \\
\text { quitting }\end{array}$ & $\begin{array}{l}\text { Hours } \\
\text { in a day }\end{array}$ & $\begin{array}{c}\text { Hours } \\
\text { in a week }\end{array}$ \\
\hline (1) Wrong to health & 8 & $26.0 \pm 5.1$ & $92.3 \pm 11.3$ & $53.1 \pm 25.5^{*}$ & $16.9 \pm 2.0$ & $3.3 \pm 0.8$ & $20.9 \pm 8.7$ \\
\hline (2) No connection to health & 32 & $26.0 \pm 9.8$ & $95.3 \pm 13.2$ & $35.9 \pm 15.1$ & $15.7 \pm 1.5$ & $2.6 \pm 0.9$ & $15.0 \pm 8.4$ \\
\hline (3) Contribution to health & 21 & $32.0 \pm 10.0^{*}$ & $100.3 \pm 16.7$ & $47.8 \pm 20.6^{*}$ & $16.7 \pm 1.6$ & $3.0 \pm 0.9$ & $18.5 \pm 6.7$ \\
\hline
\end{tabular}

Each value represents the mean \pm S.D.

${ }^{*} \mathrm{p}<0.05$ compared with no connection to health.

との間には有意な正の相関関係を認めた. (1)「健 康状態を悪くした」と答えた者の所属期間と stiffness との間には有意な正の相関関係を認めた $(\mathrm{p}<0.01)$.

一方, (2)「現在の健康状態とは無関係だ」と答 えた者の所属期間及び退部した年齢と MBF 及び stiffness との間には有意な相関関係は認められな かった.

Table 9 に前述のアンケートの答えにより被験 者を分類し，その MBF 及び stiffness を示した. 質問に(3)「現在の健康増進に貢献している」と答 えた者の MBF は(2)「現在の健康状態とは無関係 だ」と答えた者より有意に高值を示した（p< 0.05).しかし, stiffness は高值であったが, 有意 な差は認められなかった。

\section{IV 考 察}

\section{1. 咬合力と骨密度}

著者らは先に現役のスポーツマンの咬合力と体 力測定値との間に有意な正の相関関係を認めた (岩崎ら, 1994)ことを報告したが, 今回, 女子学 生についても同様の結果を認めた。しかも stiffness と体力測定值との間にも有意な正の相関 関係を認めたことは, スポーツ活動により, 体力 測定値と stiffness が共に高まる可能性があるこ とを示している.

stiffness を目的変数に, MBF と BMI を説明変 数にして重回帰分析をした結果, スポーツクラブ 所属歴のある者は MBF と stiffness との間に有 意な正の相関関係 $(\mathrm{p}<0.01)$ を認めた。平野ら （1993）は老人を対象にした調査で，骨密度（第 3 腰椎を DXA 法にて測定）と咀嚼能力との間に有
意な正の相関関係 $(\mathrm{p}<0.01)$ が認められたと報告 している. 今回女子学生についても同様のことが 認められた. 咬合力とは閉口筋群, 特に咬筋の筋 力を表すものであり, 咬筋の停止部位は下顎角部 の咬筋粗面である。 $\phi$ degaard (1970a, 1970b) は下顎骨の縦断的成長の研究の結果, 最も骨の改 造現象が生じた部位は下顎角部であることを報告 し，北村ら（1975）は，下顎角部は咬筋の影響を 強く受けると報告している。また，乗松ら (1990) は背筋力と腰椎骨密度との間, 及び大腿四頭筋力 と大腿骨中枢端骨密度との間に有意な正の相関関 係を認めたことを報告していることから，咬合力 と澦骨の骨密度との間には有意な相関関係があろ うと推測される。このように骨密度は運動により 増加することが認められている，その理由を楊 （1991）は，運動すなわち骨へ負荷をかけることで 骨に圧電効果が生じ, 負荷側にマイナス電位が生 じカルシウムイオンを引き寄せること, また運動 により骨内の血流が増加することにより酸素分圧 の増加とアルカリ化により骨溶解を防ぎ, 骨芽細 胞を活性化させ骨塩濃度を増加させるためと推測 している。このように, 咬合力が高い者は身体の 筋力が高く stiffness も高いのであろう. 一方, ス ポーツクラブの所属歴のない者でも stiffness と BMI との間に有意な正の相関関係が認められた. 同様に中村ら (1994) は BMI と stiffness との間に 有意な正の相関関係 $(\mathrm{p}<0.01)$ を認めたことを報 告している．その原因として体重は骨への負荷と なり骨密度を増加させること, また骨の形成に促 進的に㗢くことが知られているエストロゲンが肥 満者ではより多く生産されるためであろうと推測 している. 
2. スポーツクラブ所属期間と運動量

以上のように本研究では MBF と stiffness が 運動により増加する可能性を認めた。そこでス ポーツクラブ所属期間と運動量が両者にいかなる 影響を及ほすすか調べるためにアンケート調查を 行ったわけである.その結果, MBF と stiffness を 高める可能性があるのは，所属期間と退部した年 秢であった。すなわち所属期間が長い程，また退 部した時から現在までの時間が短い程, $\mathrm{MBF}$ と stiffness は高值を示す可能性がある。しかし，1 日及び 1 週間の練習時間と MBF 及び stiffness とは関係がみられなかった。ただし所属期間が長 い者及び退部した年齢が遅い者は，1 日及び 1 週 間の練習時間が長い傾向にあり，また 1 週間の練 習日数が長い者は 1 日の練習時間が長い傾向にあ ることが認められた。これはスポーツ活動に熱中 する者の気質のためであろうと思われる，以上の ことは, 退部した年齢別にわけた MBF, stiffness, 1 日及び 1 週間の練習時間にも表れている (Table 7).すなわち, 現在スポーツクラブに所属 している者の MBFや stiffness は所属しなかっ た者のそれより有意に高值を示し，また17～18歳 時に退部した者は, 1 日及び 1 週間の練習時間が, 他の年歯時に退部した者のそれと比べて有意差は なかったにもかかわらず，MBFゃ stiffness は高 值を示した。このように過去のスポーツ活動は現 在の MBF や stiffness を高める可能性があるが, スポーツ活動を停止してからの時間が経過すれば するほど現在の MBF やstiffness は低くなるこ とを認めた．次にアンケートの健康に関する意識 調査の結果, 過去のスポーツ活動が「現在の健康 増進に貢献している」と答えた者は，「現在の健康 状態とは無関係だ」と感じている者と比べて, $\mathrm{MBF}$ が有意に高值（p<0.05）であったこと，及 び stiffness が有意ではなかったが高值であった ことで, 過去のスポーツ活動が有意義な効果をも たらし, 意識にも表れたのであろうと考えられる. 一方，健康に関する意識で被験者を分類し，それ ぞれの者の，1 日及び 1 週間の練習時間を分析し たが, 有意差は認められなかった。このことは,
MBF や stiffness に影響を及ぼすのは，1日及び 1 週間の練習時間ではなく, 運動の内容であろう と考えられる。運動の負荷が適切であった者は, 健康に関する意識調査で,「現在の健康増進に貢献 している」と感じているのであろう。一方，「健康 状態を悪くした」と感じている者の所属期間は, 「現在の健康状態とは無関係だ」と感じている者の 所属期間より有意に長かった。また，1日及び 1 週間の練習時間も長かったこと(有意ではないが) は運動の負荷が強かったために体を悪くしたと感 じている, あるいは何らかのスポーツ障害が実際 に生じたことが推察される。ここで注目すべき点 は「健康状態を悪くした」と感じている者は, 期 間や練習時間が長くても MBFや stiffness は高 くないことである.適切な運動をした場合にのみ, MBF やstiffness が高くなり,「健康増進に貢献し ている」と意識できるのであろう.

3. 骨粗䉘症との関連について

近年，骨粗䇗症患者が増加している（折茂ら， 1989)。特に骨粗䇪症の特有な症状である大腿骨頸 部骨折はいわゆる寝たきり老人を発生させ，高龄 化社会の到来とともに憂慮すべき事態と危惧され る.このような社会的背景のなか, 各種の骨密度 測定装置が開発されている。なかでも DXA 法と 超音波法の有効性が報告されているが, 超音波法 は他の骨量測定装置と異なり放射線を用いないた め, 放身線管理の必要がなく, また被験者に対し て非侵襲的であることから集団検診においては有 効であると考え，これを今回の調査に採用した。 骨粗箖症は閉経に伴うエストロゲン産生の低下の ため高年女性に多い疾患である。従って太田ら (1995) は，エストロゲンの影響が高いと考えられ る海綿骨の多い腰椎では, 閉経後のホルモン補充 療法を受ければ対照群に比べて骨密度が25\%高く なるが，荷重負荷の影響を強く受けると考えられ る皮質骨の多い大腿骨近位部では，同様のホルモ ン補充療法ではほとんど差が認められないと報告 している，骨密度は加齢の影響を強く受け，30歳 前後で最大值を示した後減少し, 閉経直後から約 10年間, 骨密度の減少が加速する(宮村ら, 1994). 
従って骨粗鬆症の予防の為には, 最も骨密度が高 くなる時期までに, 効率よく骨密度を高める必要 がある、骨密度と運動に関する報告は数多くある. Wickham (1989) らは65歳以上を対象にした調査 で，カルシウム摂取不足より，日常活動性の低下 が骨粗鬆症における大腿骨頸部骨折の危険性を増 していると報告している。また楊（1991）, 林 (1990), 広田(1991)らは, 運動やレクリエーショ ンスポーツでも骨密度の増加に有効であると報告 している.一方, 宮村ら（1994）は, 過去及び現 在の運動習慣と骨密度との関係は認められなかっ たと，また，Cavanaugh ら（1988）は運動負荷が 中等度の歩行運動などでは, 閉経後の骨密度低下 を予防できないと報告している。これらのことを 考慮して著者らは, 咬合力を高めるような運動を することが以下のような理由で骨密度を高める可 能性があると考える．前述したように乗松(1990) らは, 骨密度が負荷を受ける筋力と関係があると 述べている。そして前原は, 咬合力は歯牙, 顎関 節及び頸椎に直接影響し, 頭蓋の保持に欠かせな い要素であり咬合力は運動機能や能力に関与する と述べている。 また著者らも背筋力, 握力が咬合 力と有意な正の相関関係があることを認めたよう に身体の筋力は咬合力と有意な相関関係がある. 従って骨密度と咬合力との間には有意な正の相関 関係が成立すると考える。よって著者らは, 骨粗 弉症を予防する目的で骨密度を高めるためには, 若い時に咬合力を高めるような運動を行うことが 必要であろうと考える。

\section{V ま と め}

咬合力と骨密度との関係を検討する目的で 91 名 の女子学生 (平均年齢19.6 0.5 歳) について咬合 力, 及び超音波法で右踵骨の stiffness を測定し た. 咬合力については, 左右 2 回ずつ測定し左右 のうち大きい方を採用しこれを maximum biting force (以下 MBF と略す) として解析して以下の 結果を得た。

1. スポーツクラブ所属歴のある者の $\mathrm{MBF}$ は $28.3 \pm 9.7 \mathrm{kgf}$, stiffness は96.5 14.5 であり, 所
属歷のない者のそれより有意な高值を示した $(\mathrm{p}<0.05)$.

2. スポーツクラブ所属歴のある者の $\mathrm{MBF}$ 及 び stiffness と握力 $(\mathrm{p}<0.01)$, 背筋力 $(\mathrm{p}<0.01)$, 肺活量 $(\mathrm{p}<0.05)$ との間には有意な正の相関関係 が認められた. しかし所属歴のない者の MBF 及 びstiffness と体力測定值との間には有意な相関 関係は認められなかった。

3. 重回㷌分析を行った結果, スポーツクラブ所 属歴のある者の stiffness と MBF との間の偏相 関係数は $0.504 （ \mathrm{p}<0.01 ）$ であり有意な正の相関 関係を認めたが, stiffness と BMI 及び所属歴の ない者の stiffness と MBF との間には有意な相 関関係は認められなかった。しかし所属歴のない 者の stiffness と BMI との間の偏相関係数は $0.423(\mathrm{p}<0.05)$ であり有意な正の相関関係が認 められた。

4. MBF や stiffness は 1 週間の練習日数や練 習時間とは関係がなく, 所属期間が長い者や退部 した年齢が遅い者が大きい傾向にあった。

5. 現在スポーツクラブに所属している者の MBF やstiffness は所属しなかった者のそれより 有意に高値を示した。また17～18歳時に退部した 者の MBF やstiffness は所属しなかった者のそ れより有意に高值を示した。しかし，13～14歳時 に退部した者の MBFやstiffnessは所属しな かった者のそれょり低值であった。

6. アンケート調查の結果, 過去のスポーツ活動 が「現在の健康増進に貢献している」と答えた者 の MBF は,「現在の健康状態とは無関係だ」と答 えた者のそれょり有意に高値を示した。しかし stiffness は高值ではあったが，有意な差は認めら れなかった。

\section{文献}

Cavanaugh, D.J., et al. (1988) : Brisk walking does not stop bone loss in post menopausal women, Bone, 9, 201

林 泰史 (1990)：骨粗鬆症と運動, 日医会誌, 104, $1175-1176$

平林健彦（1975）：種々な下滪位における咬合力に関 
する研究，補綴誌，18，337-360

平野浩彦, 石山直欣, 鈴木隆男, 他（1993）：地域老 年者の咀嚼能力および口腔内状況に関する研究. 第 2 報. 咀罱能力と口腔内状況および身体状態との関 連について，老年歯科医学，7, 150-156

広田孝子，真砂江美，奈良正子（1991）：若年時から の骨粗箖症の䄼極的予防法, 体力研究, 77, 113-121

井上直彦 (1982)：日本人における歯と顎骨の不調和 の推移，民族衛生，48, 78-79

岩崎秀哉, 井奈波良一, 岩田弘敏 (1994)： スポーツ

マンの咬合力と体力, 日本衛生学雑誌，49,654-659

岩崎秀哉, 藤田節也, 吉田英世, 井奈波良一, 岩田弘

敏 (1995)：咬合力と頡顔面形態との関係, 日本衛 生学雑誌, 50, 683-692

河村洋二郎 (1979)：口腔生理学, 217, 永松書店, (京 都)

北村易一朗, 菊地正巳, 北川立夫, 他 (1975) : 現代 日本人下顎骨の形態についての研究, 新潟医会誌, $89,556-561$

前原 潔 (1991)：咬合と運動神経系（テンプレート 療法から), 日本歯科医誌会雑誌，43，1271-1279

宮村季浩, 飯島純夫, 浅香昭雄, 他 (1994)：骨粗秐 症危険因子の骨塩量に与える影響についての検討, 日本公衛誌，41，1122-1130

森谷良彦（1989）：補緅物と咬合力 - 咀嚼力, 歯界展 望, 74, 1355-1362

中村美詠子, 青木伸雄, 那須恵子, 他 (1994)：地域
における骨粗箖症に関する疫学的研究一超音波骨密 度測定装置を用いた検討一, 日本公衛誌, 41, 11521161

乗松尋道, 中野正春 (1990): 運動とカルシウム摂取, 総合臨床，39, 2632-2638

折茂 整, 細田 裕, 白木正孝, 他 (1989)：大腿骨 頸部骨折全国頻度調査報告，日本医事新報，3420, 43 $-45$

太田壽城, 滝本秀美 (1995)：骨粗箖症の予防と若い 女性の骨密度，週間保健衛生ニュース，779，18-21

Фdegaard, J. (1970a): Growth of the mandible studied with the aid of metal implant, Am. J. Orthod., 57, 145-157

Фdegaard, J. (1970b) : Mandibular rotation studied with the aid of metal implant, Am. J. Orthod., 58, 448-454

Wickham, C.A.C., et al. (1989) : Dietary calcium, physical activity, and risk of hip fracture: a prospective study, B.M.J., 299, 889-892

山崎 薰, 串田一博, 大村亮宏, 他 (1992)：超音波 骨量測定装置 (Achilles Ultrasound Bone Densitometer）の使用経験一測定精度と有用性の検討 -. Ther. Res., 13, 3647-3655

揚 鴻生 (1991)：骨粗䇗症の予防一運動の効果, 公 衆衛生，55, 22-26

（受稿1994.6.20；受理1995.11.10） 